Pak. J. Agri. Sci., Vol. 53(2), 399-406; 2016

ISSN (Print) 0552-9034, ISSN (Online) 2076-0906

DOI: 10.21162/PAKJAS/16.2425

http://www.pakjas.com.pk

\title{
THE INFLUENCE OF MYCORRHIZAL SPECIES ON SOUR ORANGE (Citrus aurantium L.) GROWTH UNDER SALINE SOIL CONDITIONS
}

\author{
Neslihan Y. Satir ${ }^{1, *}$, Ibrahim Ortas² and Onur Satir ${ }^{3}$ \\ ${ }^{1}$ Republic of Turkey Ministry of Food Agriculture and Livestock, Van Office 65080, Van, Turkey; ${ }^{2}$ Department of \\ Soil Science, Faculty of Agriculture, Cukurova University, Balcall, 01330, Turkey; ${ }^{3}$ Department of Landscape \\ Architecture, Faculty of Agriculture, Yuzuncu Yil University, Van, 65080, Turkey. \\ "Corresponding author's e-mail: osatir@cu.edu.tr
}

\begin{abstract}
A two-staged experiment was conducted to investigate the effects of indigenous and predefined mycorrhizae inoculation on sour orange (Citrus aurantium L.) growth under saline soil conditions. In first stage, indigenous mycorrhizae that existed in the rhizosphere of Mediterranean halophytic plants propagated by using a trap culture method. Trifolium sp. was used as the host plant. In the second stage, the effects of propagated indigenous mycorrhizae and predefined morphological species (Glomus clarum, G. caledonium and G. mosseae) on citrus plant growth were evaluated with high levels of salt (2000 $\mu \mathrm{mhos} / \mathrm{cm} \mathrm{NaCl}$ ) under greenhouse conditions. These species are produced in the method of grafting on a regular basis exists Cukurova University. Andesitic tuff: soil: compost (6:3:1) mixture were used as growth media. Shoot and root dry matter, root infections, spore production, and concentrations of $\mathrm{N}, \mathrm{P}, \mathrm{K}, \mathrm{Zn}, \mathrm{Mn}$ and $\mathrm{Cu}$ in plant tissues were analyzed. The results demonstrated that indigenous mycorrhizae, especially spores extracted from the rhizospheres of Euphorbia paralias and Ambrosia maritima, had a significant effect on citrus growth and nutrient uptake. Citrus plants inoculated with G. clarum and G. caledonium grew more efficiently than those inoculated with G. mosseae.
\end{abstract}

Keywords: Indigenous mycorrhizae, mycorrhizal species, trap culture, halophytic plant, salinity, citrus growth.

\section{INTRODUCTION}

There is a salinity problem in agriculture due to mismanagement from high inputs of fertilizer, inappropriate irrigation and deficient drainage. This is one of the most significant agricultural problems in the world, especially in arid and semi-arid soil ecosystems. Soil salinization can be controlled by a set of factors related to environmental conditions (climate, hydrology), water supply, control systems (irrigation, drainage) and cropping practices (type and density of plant cover and the plant's rooting characteristics) ( Metternicht and Zinc, 2008). Salinity stress is a major factor limiting plant growth and productivity in many regions of the world. These stresses include the accumulation of ion toxicity (e.g., $\mathrm{Na}$ and $\mathrm{Cl}$ ), ionic imbalances, osmotic stress and soil permeability problems (Epstein et al., 1980; Flowers, 1999). Salinity stress on plant systems is manifested by lowered levels of photosynthesis (Ashraf et al., 2002).

Takacs and Voros (2003) reported that arbuscular mycorrhizal fungi (AMF) might play an important role in agriculture by increasing the stress tolerance of the host plants. Among the biological approaches for enhancing plant growth under saline conditions, the role of AMF has been well established. There is considerable evidence that AMF can enhance plant growth and vigor under conditions of saline stress (Dixon et al., 1993; Juniper and Abbott, 1993; Kim and Weber, 1985; Pfeiffer and Bloss, 1988; Pond et al., 1984;
Tsang and Maun, 1999). Most native plants and crops in arid and semi-arid areas are mycorrhizal, and it has been suggested that AM fungal colonization might enhance the salt tolerance of some plants (Tain et al., 2004). Furthermore, under saline conditions, AMF can increase plant growth and the uptake of nutrients while decreasing yield losses (Al-Karaki, 2000; AlKhaliel, 2010; Ruiz-Lozano et al., 1996). Wu et al. (2010) have shown that mycorrhizal citrus seedlings exhibited more efficient antioxidant defense systems, which provided better protection against salt damage. The significance of mycorrhizal functions, as an extension of the root system of a plant, can be understood as increasing the absorptive area and improving the nutrients uptake such as $\mathrm{P}, \mathrm{Zn}$, and $\mathrm{Cu}$ (Cho et al., 2009; Ortas et al., 2002a,b). The influence of salinity on plant $\mathrm{P}$ concentration is especially important in the context of the plant's response to AM (Graham, 1986; Poss et al., 1985). In many crops, as salinity increases, plant $P$ concentrations decrease; therefore, these crops might benefit from inoculation with efficient strains of AM that are tolerant to high salinity. In addition, AMF develops an extensive additional hyphal network with the plant root system, which makes a significant contribution to the improvement of soil texture and water exchange (Bethlenfalvay and Shuepp, 1994; $\mathrm{Wu}$ et al., 2009). Furthermore, AM fungi can positively influence the establishment and growth of plants by improving their nutrient uptake, increasing their tolerance to drought and salt stress, and increasing their resistance to soil- 
borne pathogens (Azcón-Aguilar and Barea, 1997). Syvertsen and Levy (2005) reported that mycorrhizae can affect the salt tolerance of citrus roots and may increase chloride $(\mathrm{Cl})$ uptake. Improvements in physiological processes, such as photosynthetic activity or water use efficiency, have also been demonstrated in mycorrhizal plants growing under salt-stress conditions (Ruiz-Lozano et al., 1996). Many different methods have been used to propagate AM fungi, but these methods involve the growing of fungi in association with a living root system (Douds et al., 2000; Ortas, 1996; Sylvia and Jarstfer, 1994). Currently, different propagation techniques are being developed. One of these techniques is trap culture. In trap culture, after rhizospheric soil (including spores, hyphae and roots) is collected from nature, AM fungi are propagated under sterile sand + soil greenhouse conditions using host plants (INVAM, 2011). Several host plants are used in trap culture. Liu and Wang (2003) reported that the highest spore numbers and the highest number of mycorrhizal species were obtained using Trifolium repens grown in coal mine tailings. Trap cultures can be very helpful for revealing fungal community members that were undetected during the initial extraction of spores from soil in the field (Morton et al., 1995). Additionally, when spores are collected directly from soils in the field, they have many problems, such as a loss of spores and changes in the appearance of their structure. According to Maas (1987), samples that were collected from sand dunes indicated that the nourishment of sand dune plants is supported by mycorrhizae. While moderately salt-tolerant crops might continue to grow as much as $8 \mathrm{dS} \mathrm{m} \mathrm{m}^{-1}$, only halophytes can survive at higher salinities, $\geq 30 \mathrm{dS} \mathrm{m}$ (Flowers and Yeo, 1986; Maas, 1987).

Citrus plants are strongly dependent on mycorrhizae (Ortas et al., 2002a,b). In Turkey, $75 \%$ of Turkish citrus plantations are located in the Mediterranean region, and soil salinity is one of the major problems in this region. The use of mycorrhizae is important to increase the plants' resistance to the effects of salt. Indigenous mycorrhizae, which are located in the rhizosphere of Mediterranean halophytic plants, can be useful for the growth of citrus seedlings. It would be a great agricultural strategy to collect indigenous mycorrhizae from the rhizosphere of halophytic plants in order to utilize them on citrus plantations.

The aim of this research was to evaluate the effects of indigenous mycorrhizae, which were isolated from the rhizosphere of halophytic plants and termed mycorrhizal inoculums, on the growth and nutrient uptake of sour orange plants under soil conditions where salt was added experimentally. The research was based on the hypothesis that the indigenous mycorrhizal spores, which were cultured in an area with relatively high salinity, could increase the resistance of citrus plants against the effects of added salinity better than the described mycorrhizal species.

\section{MATERIALS AND METHODS}

This research was performed in two stages. The aim of the first stage was to propagate the indigenous mycorrhizae by applying the trap culture method. According to this method, rhizospheric soils from six different types of halophytic plants (Euphorbia paralias (Euphorbiaceae), Cakile maritima (Brassicaceae), Conyza canadensis (Compositae), Echium angustifolium (Boraginaceae), Inula viscosa (Compositae), and Ambrosia maritima (Brassicaceae)) were collected along the southern coast of Turkey. Roots were chopped into small fragments and the pieces were mixed with rhizospheric soil. This mixture was thoroughly homogenized $(1: 1, \mathrm{~V}: \mathrm{V})$, and the sand was sterilized twice in an autoclave $\left(121^{\circ} \mathrm{C}\right.$ for 1 hour with intervals of $24 \mathrm{~h}$ between sterilization steps). Mixtures were transferred to sterilized $1.5 \mathrm{~kg}$ plastic pots $(15 \mathrm{~cm}$ wide and $13 \mathrm{~cm}$ high). Trifolium sp., which is highly dependent on mycorrhizae and is grown extensively in the Cukurova region, was chosen as the host plant (Ortas et al., 1999). The trap culture experiment was continued for 4 months. Root and soil mixtures were kept inside the pots at a temperature of $4^{\circ} \mathrm{C}$ for 1-2 weeks after the harvest.

Mycorrhizae were isolated at the end of the harvest. The remaining roots, mycorrhizal hyphae, soil and spores were kept under cold conditions at $4^{\circ} \mathrm{C}$ until the second stage.

In the second stage of the experiment, seedlings of citrus plants (Citrus aurantium L.) were chosen as test plants and andesitic tuff: soil: compost (6:3:1) mixture were used as growth media (Table 1). Citrus seedlings were grown from seeds. When citrus seedlings had three leafs, they were transferred to three kilograms of sterilized growth medium. Mycorrhizae were inoculated at 1000 spores per pot during transferred. Growth continued for 16 weeks. The experiment was done three replicates. The plants were irrigated by 2000 mmhos salty water after eighth month to provide salinity stress.

Table 1. Chemical input of compost and andesitic tuff used in experiment.

\begin{tabular}{|c|c|c|c|c|c|c|c|c|c|c|c|c|}
\hline \multirow[b]{3}{*}{ Unit } & pH & Fire & \multicolumn{2}{|c|}{ Total } & $\mathrm{P}_{2} \mathrm{O}_{5}$ & $\mathbf{K}$ & $\mathbf{C a}$ & Mg & $\mathbf{Z n}$ & $\mathbf{F e}$ & $\mathbf{C u}$ & Mn \\
\hline & $\left(1: 1 \mathrm{H}_{2} \mathrm{O}\right)$ & lost & $\mathbf{N}$ & $\mathbf{P}$ & & & & & & & & \\
\hline & \multicolumn{8}{|c|}{$(\%)$} & \multicolumn{4}{|c|}{$(\mathrm{mg} / \mathrm{kg})$} \\
\hline Compost & 7.91 & 54.2 & 1.13 & 0.18 & - & 0.98 & 2.50 & 0.27 & 40 & 1005 & 12 & 141 \\
\hline Andesitic tuff & - & - & - & - & 0.03 & 4.3 & - & - & 0.1 & 2 & 0.2 & 3.6 \\
\hline
\end{tabular}


Table 2. According to Tukey HSD test effects of propagated mycorrhizae with Trap Culture on shoot dry weight, root dry weight, spore count and \% mycorrhizal infection of Trifolium $s p$.

\begin{tabular}{lccccc}
\hline & Shoot DM & Root DM & Infection (\%) & Spore & $\begin{array}{c}\text { Spore numbers } \\
\text { before produce }\end{array}$ \\
\hline Euphorbia paralis & $6.06 \pm 0.91 \mathrm{a}$ & $2.13 \pm 0.31 \mathrm{ab}$ & $57 \pm 11.55 \mathrm{a}$ & $67 \pm 14.43 \mathrm{bc}$ & $16 \pm 1.73 \mathrm{bc}$ \\
Cakila maritima & $2.05 \pm 0.51 \mathrm{c}$ & $0.33 \pm 0.06 \mathrm{c}$ & $57 \pm 20.82 \mathrm{a}$ & $42 \pm 18.77 \mathrm{c}$ & $8 \pm 2.00 \mathrm{~cd}$ \\
Conyza canadensis & $4.92 \pm 1.19 \mathrm{~b}$ & $1.56 \pm 0.21 \mathrm{~b}$ & $73 \pm 05.77 \mathrm{a}$ & $109 \pm 24.43 \mathrm{ab}$ & $20 \pm 4.36 \mathrm{ab}$ \\
Echium angustifolium & $6.11 \pm 0.72 \mathrm{a}$ & $2.33 \pm 0.38 \mathrm{a}$ & $63 \pm 11.55 \mathrm{a}$ & $50 \pm 13.23 \mathrm{c}$ & $10 \pm 2.00 \mathrm{~cd}$ \\
Inula vicosa & $2.64 \pm 0.39 \mathrm{bc}$ & $2.20 \pm 0.26 \mathrm{ab}$ & $86 \pm 23.09 \mathrm{a}$ & $40 \pm 05.00 \mathrm{c}$ & $7 \pm 2.64 \mathrm{~d}$ \\
Ambrosia maritima & $3.71 \pm 1.01 \mathrm{bc}$ & $0.80 \pm 0.20 \mathrm{c}$ & $60 \pm 17.35 \mathrm{a}$ & $110 \pm 9.02 \mathrm{a}$ & $25 \pm 7,28 \mathrm{a}$ \\
\hline$P$ & $* * *$ & $* * *$ & NS & $* * *$ & $* * *$ \\
\hline
\end{tabular}

Mean of the three replicates $*, * *, * * *$ significant at $\mathrm{P}<0,05-0,01-0,001$ respectively

Dry matter from plant shoots and roots, nutrient content, number of spores and root colonization (\%) were determined at the time of harvest. Root samples were first washed with tap water and then with de-ionized water, subsequently, subsamples were taken to determine mycorrhizal colonization rates.

Root colonization and spore counting: The sub-samples of root material treated with colonizing mycorrhizae were collected and cleared in a $10 \% \mathrm{KOH}$ solution $(\mathrm{w} / \mathrm{v})$ and stained using trypan blue according to the method of Phillips and Hayman (1970). The root clearing and staining procedure as well as the degree of mycorrhizal infection in the root cortex were assessed according to the method of Koske and Gemma (1989). Mycorrhizal colonization was determined using the grid-line intersection method of Giovannetti and Mosse (1980). The percentage of root infection was calculated as follows: Infection $\%=100 \mathrm{x}$ total mycorrhizal root intercepts/total root intercepts.

Spores were isolated from the rhizospheric soil samples by using the wet sieving technique (Gerdermann and Nicolson, 1963). Each fraction of soil debris and spores were passed through filter of 53 microns and transferred to a nematode counting dish. Spores were counted using a stereo microscope at a magnification of $25 \mathrm{X}$.

Plant tissue analysis: The shoots (leaves and stems) and roots were dried at $65^{\circ} \mathrm{C}$, and the relevant data were recorded. The dried citrus leaves were milled, and the concentration of $\mathrm{P}$ was determined by the Murphy and Riley (1962) method using a spectrophotometer. The concentrations of $\mathrm{Zn}, \mathrm{Cu}, \mathrm{Mn}$ and $\mathrm{K}$ were determined using an atomic absorption spectrophotometer. Total $\mathrm{N}$ concentration was measured by the semi-kjeldahl method, according to Bremner (1965).

Statistical analysis: The data were analyzed with the oneway ANOVA model to test for significant differences between the mycorrhizal applications. All statistical analyses were performed using the SPSS 10.0 program package. Tukey's Multiple Range tests were used to determine the significant differences between treatment means.

\section{RESULTS}

In the first stage of the experiment, collected healthy indigenous mycorrhizae were propagated successfully by applying the trap culture method. The best result was observed in Conyza canadensis. The spore numbers

Table 3. According to Tukey HSD test effects of propagated mycorrhiza with Trap Culture and different mycorrhiza types at sour orange on shoot dry weight, root dry weight, spore number and \% mycorrhizal infection.

\begin{tabular}{lcccc}
\hline & Shoot DM & Root DM & Spore & Infection (\%) \\
\hline Control & $0.60 \pm 0.08 \mathrm{~b}$ & $0.20 \pm 0.48 \mathrm{bc}$ & 0 & 0 \\
G. clarum & $2.08 \pm 0.16 \mathrm{ab}$ & $1.12 \pm 0.23 \mathrm{a}-\mathrm{c}$ & $43.3 \pm 12.58 \mathrm{bc}$ & $67.5 \pm 9.57 \mathrm{ab}$ \\
G. caledonium, & $2.16 \pm 0.63 \mathrm{ab}$ & $1.20 \pm 0.11 \mathrm{ac}$ & $54.5 \pm 17.06 \mathrm{bc}$ & $57.5 \pm 5 \mathrm{a}-\mathrm{c}$ \\
G. mosseae & $0.68 \pm 0.23 \mathrm{~b}$ & $0.33 \pm 0.08 \mathrm{c}$ & $40.3 \pm 6.34 \mathrm{bc}$ & $35.0 \pm 10 \mathrm{c}$ \\
Euphorbia paralis & $2.94 \pm 0.53 \mathrm{a}$ & $1.51 \pm 0.12 \mathrm{a}$ & $44.0 \pm 7.07 \mathrm{bc}$ & $62.5 \pm 17.08 \mathrm{ab}$ \\
Cakila maritima & $0.99 \pm 0.89 \mathrm{~b}$ & $0.41 \pm 0.85 \mathrm{ac}$ & $37.5 \pm 3.11 \mathrm{c}$ & $35 \pm 5.77 \mathrm{c}$ \\
C. canadensis & $1.85 \pm 0.41 \mathrm{ab}$ & $1.02 \pm 0.37 \mathrm{ac}$ & $45.3 \pm 11.59 \mathrm{bc}$ & $65 \pm 5.77 \mathrm{ab}$ \\
E. angustifolium & $1.33 \pm 0.64 \mathrm{ab}$ & $0.97 \pm 0.26 \mathrm{ac}$ & $35.6 \pm 2.5 \mathrm{~cd}$ & $42.5 \pm 5 \mathrm{bc}$ \\
Inula viscosa & $1.56 \pm 1.54 \mathrm{ab}$ & $0.85 \pm 0.67 \mathrm{ac}$ & $42.3 \pm 4.03 \mathrm{bc}$ & $70 \pm 21.60 \mathrm{a}$ \\
A. maritima & $2.33 \pm 0.18 \mathrm{ab}$ & $1.55 \pm 0.14 \mathrm{a}$ & $100.6 \pm 42.56 \mathrm{a}$ & $45 \pm 12.91 \mathrm{ac}$ \\
\hline$P$ & $* * *$ & $* * *$ & $* *$ & $* * *$ \\
\hline
\end{tabular}

Mean of the three replicates $*, * *, * * *$ significant at $\mathrm{P}<0,05-0,01-0,001$ respectively 
increased from 20 to 109 and infection was determined $73 \%$. As a result of that shoot dry matter was $4.92 \mathrm{~g}$, root dry matter was 1.56 g. Nevertheless, Euphorbia paralias plants had $57 \%$ infection, Echium angustifolium plants had 63\% infection and also these plants had the best results of shoot dry matter and root dry matter. Euphorbia paralias plants had $6.06 \mathrm{~g}$ shoot dry matter, $2.13 \mathrm{~g}$ root dry matter. Echium angustifolium plants had $6.11 \mathrm{~g}$ shoot dry matter, $2.33 \mathrm{~g}$ root dry matter. Although, the highest spore numbers were recorded from Ambrosia maritima plants, this result did not affect root and shoot growth as much as those from Euphorbia paralias and Echium angustifolium. On the other hand, the lowest spore count was obtained from rhizospheric soil inoculation of Inula viscosa, Cakile maritima plants (Table 2). Nevertheless, Inula viscosa had $86 \%$ infection, Cakile maritima had $57 \%$ infection. However, these indigenous mycorrhizae did not affect root and shoot growth.

All of the results demonstrated that spores collected from halophytic plants were propagated successfully and that indigenous mycorrhizae from Euphorbia paralias had a significant effect on plant growth.

In the second stage of this experiment, propagated indigenous mycorrhizal spores and predefined mycorrhizal spores were inoculated into citrus seedlings to compare together. The best results were obtained in plants that were inoculated with indigenous mycorrhizae from Euphorbia paralias (Table 3). These mycorrhizae adapted to citrus seedlings successfully and determined 44 spore, $62 \%$ infection. As a result of that, $2.94 \mathrm{~g}$ shoot dry matter, $1.51 \mathrm{~g}$ root dry matter were obtained. Ambrosia maritima had 100 spore count and $45 \%$ infection and Conyza canadensis had 45 spore count and $65 \%$ infection. Also these infection results affected to shoot and root growth positively.

In general, the lowest root growth was measured in plants that were inoculated with $G$. mosseae and the indigenous mycorrhizae obtained from Cakile maritima (Table 3).

When comparing described mycorrhizae with indigenous mycorrhizal inoculations in plants such as Cakile maritima, we found that they produce as much dry weight of G. mosseae as other inoculated plants. However, when root growth and other values were considered, indigenous mycorrhizae that had been found on Cakile maritima were more successful than G. mosseae. Although indigenous mycorrhizae that were propagated from Ambrosia maritima had the highest number of spores, the results were similar to those of the other indigenous species (Table 3 ).

The effects of indigenous mycorrhizae collected from halophytic plants such as Euphorbia paralias, Ambrosia maritima, Inula viscosa, and Echium angustifolium on citrus plant growth were assessed (Fig. 1). Mycorrhizal species from Cakile maritime were not successful than the other indigenous species.
Although the spore numbers from Inula viscosa were found to be lower than those from other plants, Inula viscosa had the highest root colonization and performance scores (Fig. 1). Furthermore, G. caledonium and G. clarum AM-inoculated plants were observed to have much better shoot and root growth than the other species.

The nitrogen concentrations in the tissues of citrus plants differed between the mycorrhizal inoculums, and it was found that the control plants had a $2.80 \% \mathrm{~N}$ concentration, the indigenous mycorrhizae obtained from the rhizosphere of Euphorbia paralias had a $2.90 \% \mathrm{~N}$ concentration, Cakile maritima had a $3.34 \% \mathrm{~N}$ concentration and the G. mosseaeinoculated plants had a $2.65 \% \mathrm{~N}$ concentration. Plant tissue in the control plant was determined to have a $1.50 \mathrm{~K} \%$; in the inoculated Euphorbia paralias and Cakile maritima plants, $\mathrm{K}$ levels were recorded at $2.72 \mathrm{~K} \%$ and $2.49 \mathrm{~K} \%$, respectively, while G. mosseae-inoculated plants had $1.60 \% \mathrm{~K}$ concentrations.

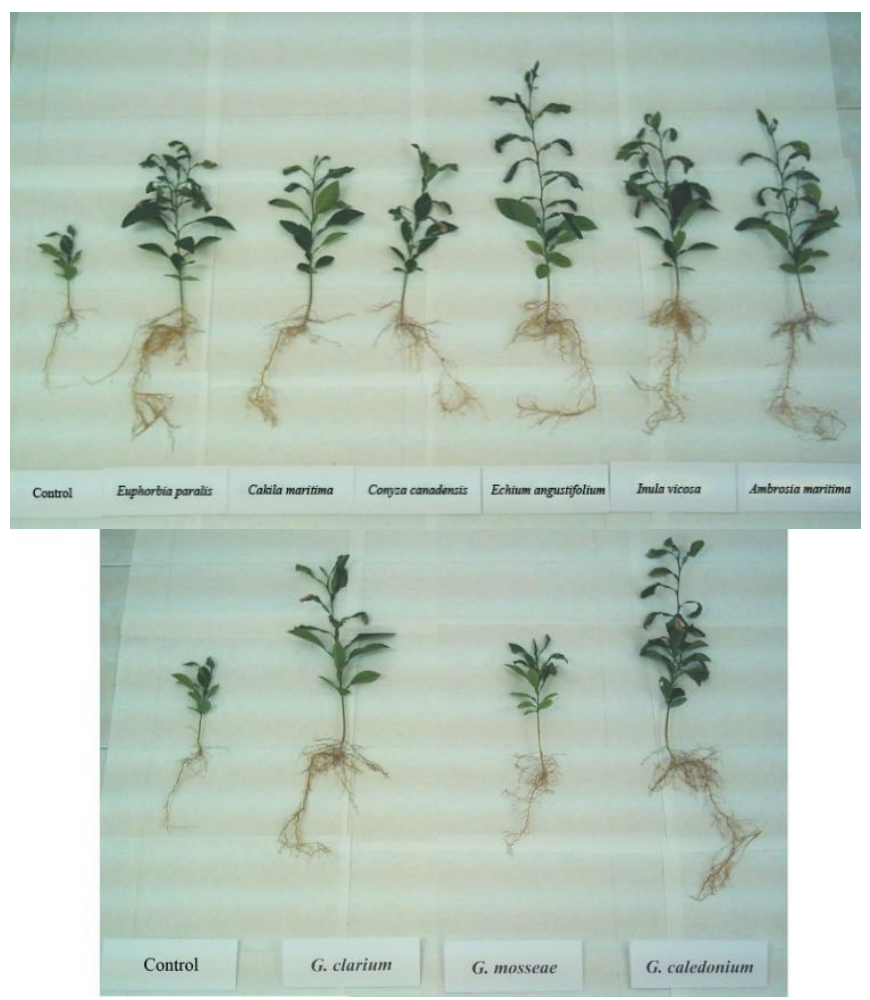

Figure 1. Root and shoot growth of sour orange inoculated with Euphorbia paralias, Cakile maritima, Conyza canadensis, Echium angustifolium, Inula viscosa, Ambrosia maritime and Glomus. clarium, G. mosseae, G. caledonium. 
Influence of mycorrhizal species on sour orange

Table 4. According to Tukey HSD test effects of propagated mycorrhiza with Trap Culture and different mycorrhiza types at sour orange on $N, P$ and $K$ concentration.

\begin{tabular}{lccc}
\hline & $\mathbf{N}(\boldsymbol{\%})$ & $\mathbf{P}(\boldsymbol{\%})$ & $\mathbf{K}(\boldsymbol{\%})$ \\
\hline Control & $2.80 \pm 0.16 \mathrm{bc}$ & $0.05 \pm 0.01 \mathrm{~b}$ & $1.50 \pm 0.15 \mathrm{c}$ \\
G. clarium & $2.15 \pm 0.10 \mathrm{e}$ & $0.09 \pm 0 \mathrm{ab}$ & $1.50 \pm 0.14 \mathrm{c}$ \\
G. caledonium & $2.65 \pm 1.50 \mathrm{~b}-\mathrm{d}$ & $0.06 \pm 0.02 \mathrm{~b}$ & $1.34 \pm 0.14 \mathrm{c}$ \\
G. mosseae & $2.65 \pm 0.59 \mathrm{~b}-\mathrm{d}$ & $0.12 \pm 0.03 \mathrm{ab}$ & $1.60 \pm 0.28 \mathrm{c}$ \\
Euphorbia paralis & $2.90 \pm 0.19 \mathrm{ab}$ & $0.15 \pm 0.03 \mathrm{a}$ & $2.72 \pm 0.21 \mathrm{a}$ \\
Cakila maritima & $3.34 \pm 0.26 \mathrm{a}$ & $0.07 \pm 0.05 \mathrm{ab}$ & $2.49 \pm 0.42 \mathrm{ab}$ \\
Conyza canadensis & $2.18 \pm 0.17 \mathrm{de}$ & $0.07 \pm 0.03 \mathrm{ab}$ & $1.88 \pm 0.36 \mathrm{bc}$ \\
Echium angustifolium & $2.46 \pm 0.73 \mathrm{c}-\mathrm{e}$ & $0.13 \pm 0.04 \mathrm{ab}$ & $1.94 \pm 0.26 \mathrm{bc}$ \\
Inula viscosa & $2.75 \pm 1.55 \mathrm{~b}-\mathrm{d}$ & $0.11 \pm 0.07 \mathrm{ab}$ & $1.38 \pm 0.42 \mathrm{c}$ \\
Ambrosia maritima & $2.32 \pm 0.18 \mathrm{c}-\mathrm{e}$ & $0.13 \pm 0.01 \mathrm{ab}$ & $1.88 \pm 0.09 \mathrm{bc}$ \\
\hline $\mathrm{P}$ & $* * *$ & $* *$ & $* * *$ \\
\hline
\end{tabular}

Mean of the three replicates $*, * *, * * *$ significant at $\mathrm{P}<0,05-0,01-0,001$ respectively

Table 5. According to Tukey HSD test effects of propagated mycorrhiza with Trap Culture and different mycorrhiza types at sour orange on $\mathrm{Mn}, \mathrm{Cu}$, and $\mathrm{Zn}$ concentration.

\begin{tabular}{llcc}
\hline & Zn $\mathbf{( p p m )}$ & Mn $(\mathbf{p p m})$ & Cu (ppm) \\
\hline Control & $13.12 \pm 0.67 \mathrm{~b}$ & $25.00 \pm 3.92 \mathrm{~b}-\mathrm{d}$ & $23.05 \pm 0.57 \mathrm{ab}$ \\
G. clarium & $18.55 \pm 4.61 \mathrm{ab}$ & $13.25 \pm 2.99 \mathrm{~d}$ & $23.60 \pm 1.76 \mathrm{ab}$ \\
G. caledonium- & $15.63 \pm 4.12 \mathrm{~b}$ & $16.75 \pm 3.86 \mathrm{~cd}$ & $20.80 \pm 0.52 \mathrm{a}-\mathrm{c}$ \\
G. mosseae & $13.68 \pm 1.64 \mathrm{~b}$ & $27.50 \pm 1.91 \mathrm{a}-\mathrm{c}$ & $23.95 \pm 0.33 \mathrm{a}$ \\
Euphorbia paralis & $26.18 \pm 5.17 \mathrm{a}$ & $39.00 \pm 5.03 \mathrm{a}$ & $17.03 \pm 1.28 \mathrm{~d}$ \\
Cakila maritima & $19.08 \pm 5.03 \mathrm{ab}$ & $30.25 \pm 8.1 \mathrm{ab}$ & $17.10 \pm 3.27 \mathrm{~cd}$ \\
Conyza canadensis & $15.50 \pm 2.1 \mathrm{~b}$ & $22.50 \pm 4.99 \mathrm{~b}-\mathrm{d}$ & $17.87 \pm 1.17 \mathrm{~cd}$ \\
Echium angustifolium & $22.62 \pm 5.82 \mathrm{ab}$ & $33.50 \pm 3.51 \mathrm{ab}$ & $20.80 \pm 1.92 \mathrm{a}-\mathrm{c}$ \\
Inula vicosa & $15.43 \pm 6.19 \mathrm{~b}$ & $25.25 \pm 5.97 \mathrm{~b}-\mathrm{d}$ & $20.18 \pm 1.59 \mathrm{~b}-\mathrm{d}$ \\
Ambrosia maritima & $18.7 \pm 2.91 \mathrm{ab}$ & $23.00 \pm 6.68 \mathrm{~b}-\mathrm{d}$ & $23.03 \pm 0.95 \mathrm{ab}$ \\
\hline$P$ & $* * *$ & $* * *$ & $* * *$ \\
\hline
\end{tabular}

Mean of the three replicates *,**,*** significant at $\mathrm{P}<0,05-0,01-0,001$ respectively

According to $\mathrm{N} \%$ and $\mathrm{K} \%$ concentration, inoculated and noninoculated plants had close results. However, when considered $\mathrm{P} \%$ concentration, inoculated plants had remarkable results.

While the non-inoculated control plant was found to have a $0.05 \% \mathrm{P}$ concentration, the plants that were inoculated with cultured mycorrhizae, such as Echium angustifolium, Inula viscosa, Euphorbia paralias and Ambrosia maritime, were found to have $0.13,0.11,0.15$ and $0.13 \% \mathrm{P}$ concentrations, respectively. The plants inoculated with $G$. mosseae were found to have a $0.12 \% \mathrm{P}$ concentration. (Table 4 ).

In addition, $\mathrm{Zn}, \mathrm{Cu}$ and $\mathrm{Mn}$ concentrations were examined. While Euphorbia paralias (plants inoculated with cultured indigenous mycorrhizae) was found to have a $26.18 \mathrm{mg} \mathrm{kg}^{-1}$ zinc concentration, control plants had a $13.12 \mathrm{mg} \mathrm{kg}^{-1} \mathrm{Zn}$ concentration and the G. clarum-inoculated plants were found to contain $18.55 \mathrm{mg} \mathrm{kg}^{-1}$ of $\mathrm{Zn}$ (Table 5). The non-inoculated control plants had $25.0 \mathrm{mg} \mathrm{kg}^{-1} \mathrm{Mn}$, while the G. mosseaeinoculated plants had $27.5 \mathrm{mg} \mathrm{kg}^{-1} \mathrm{Mn}$, Euphorbia paraliasinoculated plants had $39 \mathrm{mg} \mathrm{kg}^{-1} \mathrm{Mn}$ and Echium angustifolium- inoculated plants had $33.5 \mathrm{mg} \mathrm{kg}^{-1}$. The citrus tissue $\mathrm{Cu}$ concentration in the non-inoculated control plants was $23.05 \mathrm{mg} \mathrm{kg}^{-1}$ and the G. mosseae, G. clarum and Ambrosia maritima -inoculated plants had similar results (Table 5).

\section{DISCUSSION}

Salinity is one of the main problems that affect agricultural practices in the Mediterranean. However, there has been some research on methods to reduce salinization, such as establishing drip irrigation systems. This strategy is financially supported by the government; however, reduced salinity will not be enough to protect the citrus farms from salinization risk in the future.

Isolating indigenous mycorrhizal spores from the rhizosphere of naturally salty habitats, and using these mycorrhizal spores to improve citrus seedling growth and nutrient uptake under salt stress conditions could be an important agricultural 
strategy, when compared with using described mycorrhizal species.

Mycorrhizal spores were collected from the rhizosphere zones of halophytic plants located in and near natural saline regions, and the spores were propagated using trap culture method in order to use the mycorrhizae to inoculate citrus seedlings. In the greenhouse experiment, significant growth was detected in the mycorrhiza-inoculated citrus treatments compared with that of the control treatments (Fig.1, Table 3). Indigenous mycorrhizae that existed in the rhizosphere of Euphorbia paralias inoculated citrus seedlings were found to have the highest root and shoot growth. However, G. mosseae and indigenous mycorrhizae that existed in the rhizosphere of Cakile maritima did not demonstrate similar performance (Table 3), as expected. Cakan et al. (2006) reported that Euphorbia paralias plants had $85 \%$ root colonization at the same sand dunes.

Inoculations with the indigenous and the described mycorrhizae were found to significantly increase root colonization when compared with the non-inoculated control plants. However, G. mosseae inoculated plants and spores cultured in the Cakile maritima rhizosphere were found to have less root colonization (35\%) than other inoculations. Previously, Ortas et al. (2002) found that, for unknown reasons, G. mosseae-inoculated sour orange seedlings had less root colonization. Because the indigenous mycorrhizal fungi recovered from the halophytic plant rhizosphere were not taxonomically classified, it is not known which specific types of mycorrhizal species exist in the inoculums. It is important to research the type of mycorrhizal species in the region in different citrus orchards and halophytic plants as well.

The spore counts taken from the Ambrosia maritima and Euphorbia paralias plant rhizospheres did more than described mycorrhizae in citrus plantations. The ability of mycorrhizal fungi to enhance citrus growth has been described many times, and the differences among fungi have been reported by several authors (Ortas et al., 2002a; Vinayak and Bagyaraj, 1990).

In all of the experimental treatments, the $\mathrm{Zn}$ concentration in the citrus plants was found to be higher than in the control treatments. Mycorrhizal inoculation was increased the concentrations of $\mathrm{Zn}$ (Tables 5). In addition, the results showed that Euphorbia paralias-inoculated citrus plants had the highest $\mathrm{P}, \mathrm{Zn}$ and $\mathrm{K}$ uptake. It appears that the $\mathrm{P}$ uptake is accompanied by Zn uptake in Euphorbia paralias-inoculated plants. Similarly, Ortas et al. (2002b) found that mycorrhizal inoculation increased $\mathrm{P}$ and $\mathrm{Zn}$ content in citrus plants. It has been reported that mycorrhiza-inoculated citrus seedlings had high plant growth and $\mathrm{P}, \mathrm{K}, \mathrm{Fe}, \mathrm{Cu}$ and $\mathrm{Zn}$ uptake. The influence of salinity on plant $\mathrm{P}$ concentration is especially important for many crops (Poss et al., 1985), and it is suggested that selecting efficient strains of mycorrhizae may increase their tolerance of soil salinity.

The enhanced accumulation of these micronutrients is vital to physiological processes that impact yield of citrus plants. It has been indicated by Poss et al. (1985) that greater nutrient acquisition in response to AMF colonization is a plant strategy for improving salt stress tolerance as well.

This study showed that indigenous mycorrhizae that exist in halophytic plants are even more efficient at improving plant growth than selected known mycorrhizal types. The results encouraged us to collect indigenous spores from marginal soil conditions and to re-inoculate them in salt-sensitive plants, such as citrus. Because rhizospheric soil contains other soil organisms, the factors linked to the biological and chemical characteristics of soil, even the physical parameters, must have a large influence on mycorrhizal performance (Schreiner, 2003; Schreiner and Mihara, 2009) and plant growth. Additionally, mycorrhizal inoculation has been reported to directly improve plant nutrition (Gerdermann, 1968) through the fungal hyphae and thereby affect root architecture (Linderman, 1992) by increasing the number of finer lateral roots. On the other hand, (Wu et al., 2010) indicated that the suppressed growth and colonization of arbuscular mycorrhizae under higher salinity might be attributed to the reduced hyphal extension of the AMF.

The results show that indigenous spores collected from the rhizosphere of Euphorbia paralias are the most efficient variety. Therefore, further study of this plant's rhizosphere rather than the mycorrhizal spores is necessary. It is also important to examine the effects of other soil beneficial organisms on plant growth.

Citrus inoculation with selected AM fungi and indigenous spores was found to be beneficial for the establishment and growth of the rootstock of sour orange. It is important to isolate and classify the rhizospheric soils of the indigenous halophytic plants to inoculate citrus seedlings with selected inoculations. As a result, applied mycorrhizae should be detected for better citrus seedling production. Indigenous mycorrhizal usage could be a new agricultural strategy for the management of citrus growth in naturally saline soils for sustainable agriculture.

Conclusions: Inoculation with indigenous mycorrhizae increases citrus growth and nutrient concentrations. Plant growth and nutrient concentrations were significantly higher in soils receiving described mycorrhizal species. Indigenous mycorrhizal species were as efficient as described mycorrhizal species. Indigenous mycorrhizal spores extracted from saline areas significantly affected the growth of citrus plants under high salt application. The effect of indigenous mycorrhizal species extracted from different halophytic plant 
species should be further studied as remedies for stress factors.

\section{REFERENCES}

Al-Karaki, G. 2000. Growth and mineral acquisition by mycorrhizal tomato grown under salt stress. Mycorrhiza10:51-54.

Al-Khaliel, A.S. 2010. Effect of salinity stress on mycorrhizal association and growth response of peanut infected by Glomus mosseae. Plant Soil Env. 56:318-324.

Ashraf, M.Y., K. Akhtar, G. Sarwar and M. Ashraf. 2002. Evaluation of arid and semi-arid ecotypes of guar (Cyamopsis tetragonoloba L.) for salinity $(\mathrm{NaCl})$ tolerance. J. Arid Environ. 52:473-482.

Azcón-Aguilar, C. and J.M. Barea. 1997. Applying mycorrhiza biotechnology to horticulture: significance and potentials. Sci. Hortic. 68:1-24.

Bethlenfalvay, G.J. and H. Schuepp. 1994. Arbuscular Mycorrhizae and Agrosystem Stability. In: S. Gianinazzi and H. Schuepp (eds.), Impact of arbuscular mycorrhizae on sustainable agriculture and natural ecosystems. Birkhause Basel, pp.117-131.

Bremner, J.M. 1965. Inorganic Forms of Nitrogen. In: C.A. Black, D.D. Evans, I.E. Evsminger, F.E. Clerk and J.L. White (eds.), Methods of Soil Analysis. American Society of Agronomy Madison, pp.93-149.

Cakan, H. and C. Karataş. 2006. Interactions between mycorrhizal colonization and plant life forms along the successional gradient of coastal sand dunes in the eastern Mediterranean Turkey. Ecol. Res. 21:301-310.

Cho, E.J., D.J. Lee, C.D. Weea, H.L. Kim, Y.H. Cheong, J.S. Cho and B.K. Sohn. 2009. Effects of AMF inoculation on growth of Panax ginseng C.A. Meyer seedlings and on soil structures in mycorrhizosphere. Sci. Hortic. 122:633-637.

Dixon, R.K., M.V. Rao and V.K. Garg. 1993. Salt stress affects in vitro growth and in situ symbioses of ectomycorrhizal fungi. Mycorrhiza 3:63-68.

Douds, D.D., V. Gadkar and A. Adholeya. 2000. Mass production of VAM fungus biofertilizer. In: K.G. Mukerji, B.P. Chamola and J. Singh (eds.), Mycorrhizal biology. Kluwer Academic Plenum Publishers, New York, pp.197-215.

Epstein, E., J.D. Norlyn, D.W. Rush, R.W. Kingsbury, D.B. Kelley, G.A. Cunningham and A.F. Wrona. 1980. Saline culture of crops: A genetic approach. Science 210:399404.

Flowers, T.J. 1999. Salinization and horticultural production. Sci. Hortic. 78:1-4.

Flowers, T.J. and A.R. Yeo. 1986. Ion relations of plants under drought and salinity. Aust. J. Plant Physiol. 13:7591.
Gerdermann, J.W. and T.H. Nicolson. 1963. Spores of mycorrhizal endogeny species extracted from soil by wet sieving and decanting. Trans. Brit. Mycol. Soc. 46:235244.

Gerdermann, J.W. 1968. Vesicular-arbuscular mycorrhiza and plant growth. Annu Rev. Phyto. 6:396-418.

Giovannetti, M. and B. Mossea. 1980. An evaluation of techniques for measuring vesicular-arbuscular mycorrhiza in roots. New Phyto. 84:489-500.

Graham, J.H. 1986. Citrus mycorrhizae: potential benefits and interactions with pathogens. HortScience 21:1302-1306.

INVAM. 2011. Trap culture. Available online at http://invam.caf.wvu.edu/methods/cultures/trapcultures. htm

Juniper, S. and L. Abbott. 1993. Vesicular-arbuscular mycorrhizas and soil salinity. Mycorrhiza 4:45-57.

Kim, C.K. and D.J. Weber. 1985. Distribution of VA mycorrhiza on halophytes on inland salt playas. Plant Soi. 83:207-214.

Koske, R.E. and J.N. Gemma. 1989. A modified procedure for staining roots to detect VAM. Mycol. Res. 92:486505.

Linderman, R.G. 1992. Vesicular-arbuscular mycorrhizae and soil microbial interactions. In: G.J. Bethlenfalvay and R.G. Linderman (eds.), Mycorrhizae in sustainable agriculture. ASA Special Publication, Madison, WI, pp.45-70.

Liu, R. and F. Wang. 2003. Selection of appropriate host plants used in trap culture of arbuscular mycorrhizal fungi. Mycorrhiza 13:123-127.

Maas, E.V. 1987. Salt tolerance of plants. In: B.R. Christie (ed.), Handbook of plant science in agriculture. CRS Press, Boca Raton, FL; pp.57-75.

Metternicht, G. and J.A. Zinck. 2008. Soil salinity and salinization hazard. In: J.A. Zinck and G. Metternicht (eds.), Remote Sensing of Soil Salinization: Impact on Land Management. CRC Press Taylor and Francis Boca Raton. New York; pp.3-20.

Morton, J.B., S.P. Bentivenga and J.D. Bever. 1995. Discovery measurement and interpretation of diversity in arbuscular endomycorrhizal fungi (Glomales, Zygomycetes). Can. J. Bot. 73:25-32.

Murphy, L.J. and J.P. Riley. 1962. A modified single solution method for determination of phosphate in natural waters. Anal. Chim. Acta. 27:31-33.

Ortas, I. 1996. The influence of use of different rates of mycorrhizal inoculum on root infection, plant growth, and phosphorus uptake. Communi. Soil Sci. Plant Analy. 27:2935-2946.

Ortas, I., B. Ergun, D. Ortakci, S. Ercan and O. Kose. 1999. The production technique of mycorrhizal spore for using in large arable land. Tur. J. Agric. Forest. 23:959-968.

Ortas, I., D. Ortakçi and Z. Kaya. 2002a. Various mycorrhizal 
fungi propagated on different hosts have different effect on citrus growth and nutrient uptake. Commun. Soil Sci. Plant Analy. 33:259-272.

Ortas, I., D. Ortakçi, Z. Kaya, A. Çinar and N. Onelge. 2002 b. Mycorrhizal dependency of sour orange (Citrus aurantium L.) in term of phosphorus and zinc nutrition by different levels of phosphorus and zinc application. J. Plant Nut. 25:1263-1279.

Ortas, I., D. Ortakçi and Z. Kaya. 2002. Various mycorrhizal fungi propagated on different hosts have different effect on citrus growth and nutrient uptake. Commun. Soil Sci. Plant Analy. 33:259-272.

Pfeiffer, C.M. and H.E. Bloss. 1988. Growth and nutrition of guayule (Parthenium argentatum) in a saline soil as influenced by vesicular- arbuscular mycorrhiza and phosphorus fertilization. New Phyto. 108:315-321.

Phillips, J. and D.S. Hayman. 1970. Improved procedure for clearing roots and staining parasitic and vesicular mycorrhizal fungi for rapid assessment of infection. Trans. Br. Mycol. Soc. 55:185-191.

Pond, E.C., J.A. Menge and W.M. Jarrell. 1984. Improved growth of tomato in salinized soil by vesicular-arbuscular mycorrhizal fungi collected from saline sites. Mycologia 76:74-84.

Poss, J.A., E. Pond, J.A. Menge and W.M. Jarrell. 1985. Effect of salinity on mycorrhizal onion and tomato in soil with and without additional phosphate. Plant Soil 88:307319.

Ruiz-Lozano, J.M., R. Azcon and M. Gomez. 1996. Alleviation of salt stress by arbuscular-mycorrhizal Glomus species in Lactuca sativa plants. Physiol. Plant. 98:767-772.

Schreiner, R.P. and K.L. Mihara. 2009. The diversity of arbuscular mycorrhizal fungi amplified from grapevine roots (Vitis vinifera L.) in Oregon vineyards is seasonally stable and influenced by soil and vine age. Mycologia101:599-611.
Schreiner, R.P. 2003. Mycorrhizal colonization of grapevine rootstocks under field conditions. Am. J. Eno. Viti. 54:143-149. Sena, J.O.A., C.A. Labate and E.J.B.N. Cardoso. 2002. Micronutrient accumulation in mycorrhizal citrus under different phosphorus regimes. Acta Sci. 24:1265-1268.

Syvertsen, J. and Y. Levy. 2005. Salinity interactions with other abiotic and biotic stresses in citrus. Horttechnology 15:100-103.

Sylvia, D.M. and A.G. Jarstfer. 1994. Production of inoculum and inoculation with arbuscular mycorrhizal fungi. In: A.D. Robson, L.K. Abbot and N. Malajczuk (eds.), Management of mycorrhiza in agriculture, horticulture and forestry. Kluwer Academic Publishers, The Netherlands, pp.231-238.

Tain, C.Y., G. Feng, X.L. Li and F.S. Zhang. 2004. Different effects of arbuscular mycorrhizal fungal isolates from saline or non-saline soil on salinity tolerance of plants. App. Soil Ecol. 26:143-148.

Takacs, T. and I. Voros. 2003. Role of arbuscular mycorrhizal fungi in the water and nutrient supplies of the host plant. Novenytermeles 52:583-593.

Tsang, A. and M.A. Maun. 1999. Mycorrhizal fungi increase salt tolerance of Strophostyles helvola in coastal foredunes. Plant Ecol. 144:149-166.

Vinayak, K. and D.J. Bagyaraj. 1990. Vesicular-arbuscular mycorrhizae screened for troyer citrange. Bio. Fert. Soils 9:311-314.

Wu, Q.S., Y. Levy and Y.N. Zou. 2009. Arbuscular mycorrhizae and water relations in citrus. Tree and Forestry Science and Biotechnology. Global Science Books, pp.105-112

Wu, Q.S., Y.N. Zou, W. Liu, X.F. Ye, H.F. Zai and L.J. Zhao. 2010. Alleviation of salt stress in citrus seedlings inoculated with mycorrhiza: changes in leaf antioxidant defense systems. Plant Soil Env. 56:470-475. 